\title{
Research Know-How for Research Support Services: Preparing Information Specialists for Emerging Roles
}

\author{
Sheila Corrall \\ School of Information Sciences \\ University of Pittsburgh \\ 135 North Bellefield Avenue \\ Pittsburgh, PA 15260 \\ scorrall@pitt.edu
}

\author{
Mary Anne Kennan \\ School of Information Studies \\ Charles Sturt University \\ Locked Bag 450, \\ Silverwater NSW 2128 \\ mkennan@csu.edu.au
}

\author{
Dorothea Salo \\ School of Library \& Information \\ Studies \\ University of Wisconsin-Madison \\ 600 North Park Street \\ Madison, WI 53706 \\ salo@wisc.edu
}

\begin{abstract}
The panel will discuss the importance of understanding the research environment for providing effective information and technology support to researchers, and the implications for curricula in professional education. Our specific context is growing involvement of academic libraries and information services in managing research data, but the issues raised have wider implications for educating and developing other information specialists (e.g., in research institutes, government agencies, public libraries). Studies in the past five years have identified technical and disciplinerelated skills and knowledge gaps as potential constraints on developing library research data services. Our recent research in Australia, New Zealand, the UK, and Ireland confirmed the need for data curation and technology skills, but also found practitioners engaging in other forms of research support, and expressing needs for a multilayered introduction to the research environment, extending beyond the research skills typically gained in masters programs, including subjects such as academic culture and practice, and research policy and evaluation. The panelists represent a mix of academic and practitioner viewpoints from different countries. They will each offer their views on what is missing and should be added to graduate curricula, and how programs can make space, asking the audience to respond with their own suggestions, counter-arguments, and alternative visions, using an interactive style from the start.
\end{abstract}

\section{Keywords}

Academic libraries, curriculum development, data management, information services, professional education, research support.

ASIST 2013, November 1-6, 2013, Montreal, Quebec, Canada.

\section{INTRODUCTION}

Political, economic, and technological developments in the past decade have renewed interest globally in the role of libraries and librarians in supporting research (Auckland, 2012; Bourg, Coleman, \& Erway, 2009; MacColl \& Jubb, 2011; Webb, Gannon-Leary \& Bent, 2007). The most frequently discussed area is the curation and management of data from e-research (Garritano \& Carlson, 2009; Henty, 2008; Hey \& Hey, 2006; Lewis, 2010; Lyon, 2012; Salo, 2010a; Soehner, Steeves \& Ward, 2010; Tenopir, Birch \& Allard, 2012; Tenopir, Sandusky, Allard \& Birch, 2013), but libraries are also raising their profile with involvement in areas such as institutional repositories (Cassella \& Morando, 2012; Horwood, Sullivan, Young \& Garner, 2004; Kennan \& Kingsley, 2009; Salo, 2008), scholarly publishing (Adema \& Schmidt, 2010; Crow et al., 2012; Hahn, 2008), and bibliometrics (Ball \& Tunger, 2006; Drummond \& Wartho, 2009; Hendrix, 2010).

A recurring theme of such discussions is the need to re-skill or up-skill the information workforce to provide higher-end research support (Auckland, 2012; Henty, 2008; Lewis, 2010; Lyon, 2012; Tenopir et al, 2012). Funding from the Institute of Museum and Library Services has supported new modules, courses, specializations, and programs in the US to prepare practitioners for digital curation and data management (Harris-Pierce \& Liu, 2012; Keralis, 2012), but developments in the UK and other countries have been slower (Cox, Verbaan \& Sen, 2012; Pryor \& Donnelly, 2009). Most reports of funded curriculum initiatives have concentrated on the technical aspects of data management, but some have also highlighted the need for practitioners to understand the research process and policy context (Cox et al., 2012). Others have called for more discussion among educators and practitioners to determine future curriculum content and presentation (Harris-Pierce \& Liu, 2012; Lewis, 2010) Our own recent study of developments in library support for research in Australia, New Zealand, the UK and Ireland (Corrall, Kennan \& Afzal, 2013) confirmed the need for technical knowledge and ICT skills development, but also pointed up significant needs in the areas of research processes, research methods, research workflows, and policy contexts (national and institutional agenda). 


\section{PROBLEM STATEMENT AND RESEARCH QUESTIONS}

Academic libraries are responding to political, economic, and technological challenges in the research environment with service innovations in areas such as bibliometric support for research evaluation, and planning for the curation and management of digital research data. A survey of library practitioners in Australia, New Zealand, the UK, and Ireland found competency needs for delivering the desired services were broader and deeper than formerly acknowledged, including subjects that are not typically the focus of current curriculum initiatives, such as academic culture and practice, digital scholarship, education and research policy, intellectual property and licensing, and research assessment and evaluation, to provide a fuller understanding of the context for service development. Discussion representing the viewpoints of both academic educators and professional practitioners is needed to debate future directions for library and information science curricula to meet the needs identified. Insight gained from such a discussion can be used to inform the planning and design of both preparatory professional education programs and continuing professional development courses, and/or to suggest lines of inquiry for further investigation.

The central question is:

- What do library and information professionals need to know about research to provide effective support in the e-research environment, e.g., methodologies, policies, processes, workflows?

Related subsidiary questions include:

- What additional subjects must be included in graduate library and information science program curricula, e.g., as required or elective courses?

- What subjects or courses will be dropped to make space for the subjects identified?

- Should all library and information students undertake an empirical research project as preparation for research support roles?

- How can practitioners in the field get the research know-how required for effective support services?

\section{KEY ISSUES FOR DISCUSSION}

There is growing acknowledgment that students and practitioners in the library and information domain need education and training in technical aspects of digital data curation to enable research libraries to support institutional expectations in the area of research data management. Around one-third of ALA-accredited MLIS programs have offered a course on data curation within the last three years, of which almost half offered a concentration or specialization in the subject (Harris-Pierce \& Liu, 2012). There has been less discussion about the background knowledge and understanding of the research arena needed to complement the technical skill sets already defined.
The first task here is to identify aspects of the research environment that should be part of the core knowledge base for information specialists in research support roles. The next issue is the breadth and depth of treatment required for the topics identified, to determine how many courses might be needed. A key question is whether graduates aiming for research support roles should carry out a small-scale project to gain fuller understanding of the process of research.

Another issue is whether the subject matter deemed essential for practitioners specializing in research support should be part of the core curriculum, or only offered as a specialist track or program. A final important matter for debate is how to enable practitioners already in the field to update their knowledge and skills in a way that fits the demands of their jobs and personal/financial circumstances.

The panel will work interactively to engage the audience throughout the session. The chair will put each specified question in turn first to the panel members (rotating the order in which they speak) and then to the audience, inviting participants to provide their own perspectives on the questions and responses, or offer counter-arguments and alternative proposals.

\section{PANELISTS}

The panel members will provide complementary and contrasting expert views on the questions for debate, drawing on their varied backgrounds and experiences.

\section{Sheila Corrall}

Sheila Corrall is Professor and Chair of the Library and Information Science Program at the University of Pittsburgh School of Information Sciences, where she teaches courses on research methods and academic libraries. She was formerly Head of the University of Sheffield iSchool, and served as director of library and information services at three universities in the UK. Her research interests focus on the evolving roles and competencies of library and information professionals, and their education, training, and development needs. Recent work includes a review of the roles and responsibilities of libraries and librarians in the research data arena (Corrall, 2012), an analysis of evolving academic library specialties (Cox \& Corrall, in press), and a survey of research support services in academic libraries in Australia, New Zealand, the UK, and Ireland (Corrall et al., 2013). She serves on the editorial boards of Education for Information, Information Research, International Journal of Digital Curation, and New Review of Academic Librarianship. She also serves on the advisory panel of the JISC-funded RDMRose project, which is developing learning materials about research data management for liaison librarians in university libraries, both for the continuing professional development of practitioners and for embedding into graduate curricula. Corrall will introduce the panel, and chair the discussion, in addition to responding to the questions from the viewpoints of research, education, and practice in the US and the UK. 


\section{Mary Anne Kennan}

Mary Anne Kennan is a Senior Lecturer in the School of Information Studies at Charles Sturt University, Australia, where she teaches courses on the digital environment, research data management and research methods. Her research interests build on her $2008 \mathrm{PhD}$, which focused on scholarly communication, institutional repositories, and open access, moving into the broader areas of e-research and research data management, including the practices of sharing and collaboration. Recent work includes the survey with Corrall of research support services in academic libraries in Australia, New Zealand, the UK, and Ireland (Corrall et al., 2013). Other recent projects have investigated the management and sharing of volunteercollected data (Kennan, Williamson \& Johanson, 2012) and the role of institutional mandates in promoting open access (Kennan, 2011). Her previous experience includes 25 years working in libraries and the information world, including serving as Director of the Frank Lowy Library at the Australian Graduate School of Management in Sydney. She has also taught at the University of New South Wales and the University of Technology Sydney. She is joint editor of Australian Academic and Research Libraries and serves on the editorial board of the International Journal of ActorNetwork Theory and Technological Innovation. Kennan will respond to the questions from the viewpoints of research, education, and practice in Australia, drawing on her experience of online distance education for librarians.

\section{Dorothea Salo}

Dorothea Salo is a Faculty Associate in the School of Library \& Information Studies at the University of Wisconsin-Madison, where she teaches courses on digital curation; digital trends, tools, and debates; libraries and publishing; organization of information; and research-data management for graduate students. She also works with libraries and librarians as an independent consultant, specializing in scholarly communication and data curation. Salo formerly worked as digital repository librarian and research services librarian at the University of Wisconsin, and as digital repository services librarian at George Mason University. Relevant publications include a review of the roles and responsibilities of libraries and librarians in institutional repository development (Salo, 2008), an examination intellectual property ownership in the eresearch environment (Salo 2010b), and an analysis of the challenges facing libraries in adapting their technical infrastructures for research data management (Salo, 2010a). Salo will respond to the questions from the viewpoints of practice, training, teaching, and consultancy, drawing on her experience of working with researchers and students from different disciplinary backgrounds, in the US.

\section{REFERENCES}

Adema, J., \& Schmidt, B. (2010). From service providers to content producers: New opportunities for libraries in collaborative open access book publishing. New Review of Academic Librarianship, 16(Suppt. 1), 28-
43. Retrieved April 28, 2013, from http://www.tandfonline.com/doi/pdf/10.1080/13614533 .2010 .509542

Auckland, M. (2012). Re-skilling for research: An investigation into the roles and skills of subject and liaison librarians required to effectively support the evolving information needs of researchers. London: RLUK Research Libraries UK. Retrieved April 28, 2013, from http://www.rluk.ac.uk/content/re-skillingresearch

Ball, R., \& Tunger, D. (2006). Bibliometric analysis - a new business area for information professionals in libraries? Support for scientific research by perception and trend analysis. Scientometrics, 66, 561-577.

Bourg, C., Coleman, R., \& Erway, R. (2009). Support for the research process: An academic library manifesto. Dublin, OH: OCLC Research. Retrieved April 28, 2013, from http://www.oclc.org/content/dam/research/publications /library/2009/2009-07.pdf

Carlson, J. R., \& Garritano, J. R. (2010). E-science, Cyberinfrastructure, and the changing face of scholarship: Organizing for new models of research support at the Purdue University Libraries. In S. Walter \& K. Williams (Eds.). Staffing, sustaining, and advancing the academic library in the 21st century (pp. 234-269). Chicago, IL: Association of College and Research Libraries.

Cassella, M., \& Morando, M. (2012). Fostering new roles for librarians: Skills sets for repository managers results of a survey in Italy. LIBER Quarterly, 21, 407428. Retrieved April 28, 2013, from http://liber.library.uu.nl/publish/articles/000553/article. pdf.

Corrall, S. (2012). Roles and responsibilities: Libraries, librarians and data. In G. Pryor (Ed.). Managing research data (pp. 105-133). London: Facet.

Corrall, S., Kennan, M. A., \& Afzal, W. (2013). Bibliometrics and research data management: Emerging trends in library support for research. Library Trends, 61, 636-674.

Cox, A., \& Corrall, S. (In press). Evolving academic library specialties. Journal of the American Society for Information Science and Technology.

Cox, A., Verbaan, E., \& Sen, B. (2012). Upskilling liaison librarians for research data management. Ariadne, 70.Retrieved April 28, 2013, from http://www.ariadne.ac.uk/issue70/cox-et-al

Crow, R., Ivins, O., Mower, A., Nesdill, D., Newton, M., Speer, J., Watkinson, C. (2012). Library publishing services: Strategies for success, Final research report (Version 2.0). Washington, DC: SPARC. Retrieved 
April 28, 2013, from http://wp.sparc.arl.org/lps/

Drummond, R., \& Wartho, R. (2009). RIMS: The Research Impact Measurement Service at the University of New South Wales. Australian Academic \& Research Libraries, 40, 76-87. Retrieved April 28, 2013, from http://www.alia.org.au/publishing/aarl/40/ARRL.Vol40 .No2.2009.pdf

Garritano, J. R., \& Carlson, J. R. (2009). A subject librarian's guide to collaborating on e-science projects. Issues in Science and Technology Librarianship, 57. Retrieved April 28, 2013, from http://www.istl.org/09spring/refereed2.html\#15

Hahn, K. K. (2008). Research library publishing services: New options for university publishing. Washington, DC: Association of Research Libraries. Retrieved April 28, 2013, from http://www.arl.org/bm doc/researchlibrary-publishing-services.pdf

Harris-Pierce, R. L., \& Liu, Y. Q. (2012). Is data curation education at library and information science schools in North America adequate? New Library World, 113, 598-613.

Hendrix, D. (2010). Tenure metrics: Bibliometric education and services for academic faculty. Medical Reference Services Quarterly, 29, 183-189.

Henty, M. (2008). Developing the capability and skills to support e-research. Ariadne, 55. Retrieved April 28, 2013, from http://www.ariadne.ac.uk/issue55/henty

Hey, T., \& Hey J. (2006). E-science and its implications for the library community. Library Hi Tech, 24, 515-528.

Horwood, L., Sullivan, S., Young, E., \& Garner, J. (2004). OAI compliant institutional repositories and the role of library staff. Library Management, 25, 170-176.

Kennan, M. A. (2011). Learning to share: Mandates and open access. Library Management, 32, 302-318.

Kennan, M.A., \& Kingsley, D.A. (2009). The state of the nation: A snapshot of Australian institutional repositories, First Monday, 14(2). Retrieved April 28, 2013, from http://firstmonday.org/htbin/cgiwrap/bin/ojs/index.php/ $\mathrm{fm} /$ article/view/2282/2092.

Kennan, M. A., Williamson, K., \& Johanson, G. (2012). Wild data: Collaborative e-research and university libraries. Australian Academic and Research Libraries, $43,56-79$.

Keralis, S. D. C. (2012). Data curation education: A snapshot. In L. Jahnke, A. Asher, \& S. D. C. Keralis. The problem of data (pp. 32-43). Washington, DC: Council on Library and Information Resources. Retrieved April 28, 2013, from http:/www.clir.org/pubs/reports/pub154/pub154.pdf
Lewis, M. (2010). Libraries and the management of research data. In S. McKnight (Ed.). Envisioning future academic library services: Initiatives, ideas and challenges (pp. 145-168). London: Facet.

Lyon, L. (2012). The informatics transform: Re-engineering libraries for the data decade. International Journal of Digital Curation, 7(1), 126-138. Retrieved April 28, 2013, from http://www.ijdc.net/index.php/ijdc/article/view/210/27 9

MacColl, J., \& Jubb, M. (2011). Supporting research: Environments, administration and libraries. Dublin, OH: OCLC Research. Retrieved April 28, 2013, from http://www.oclc.org/resources/research/publications/lib rary/2011/2011-10.pdf

Pryor, G., \& Donnelly, M. (2009). Skilling up to do data: Whose role, whose responsibility, whose career? International Journal of Digital Curation, 4(2), 158170. Retrieved April 28, 2013, from http://www.ijdc.net/index.php/ijdc/article/view/126

Salo, D. (2008). Innkeeper at the roach motel. Library Trends, 57, 98-123. Retrieved April 28, 2013, from https:/www.ideals.illinois.edu/handle/2142/10678

Salo, D. (2010a). Retooling libraries for the data challenge. Ariadne, 64. Retrieved April 28, 2013, from http://www.ariadne.ac.uk/issue64/salo

Salo, D. (2010b). Who owns our work? Serials, 23, 191195. Retrieved April 28, 2013, from http://uksg.metapress.com/content/122u0tqlh1j50v11/ful ltext.pdf

Soehner, C., Steeves, C., \& Ward, J. (2010). e-Science and data support services: A study of ARL member institutions. Washington, DC: Association of Research Libraries. Retrieved April 28, 2013, from http://www.arl.org/bm doc/escience report2010.pdf

Tenopir, C., Birch, B., \& Allard, S. (2012). Academic libraries and research data services: Current practices and plans for the future, An ACRL white paper. Chicago, IL: Association of College \& Research Libraries.

http://www.ala.org/acrl/sites/ala.org.acrl/files/content/p ublications/whitepapers/Tenopir Birch Allard.pdf

Tenopir, C., Sandusky, R. J., Birch, B., \& Allard, S. (2013). Academic librarians and research data services: Preparation and attitudes. IFLA Journal, 39, 70-78. Retrieved April 28, 2013, from http://www.ifla.org/files/assets/hq/publications/iflajournal/ifla-journal-39-1_2013.pdf

Webb, J., Gannon-Leary, P., \& Bent, M. (2007). Providing effective library services for research. London: Facet. 